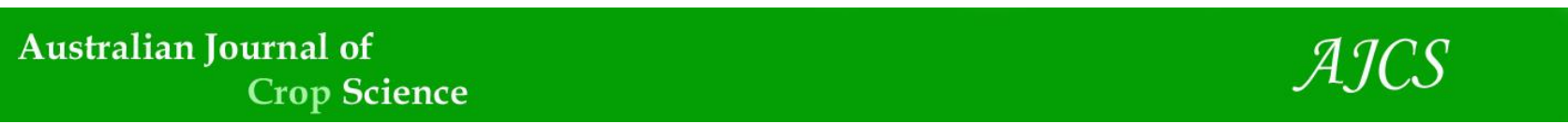

AJCS 15(06):811-815 (2021)

ISSN:1835-2707

doi: 10.21475/ajcs.21.15.06.p2786

Research Note

\title{
Lines derived from coffee BA-10 with resistance to Pseudomonas syringae under field conditions with simultaneous natural infections of the pathovars garcae and tabaci
}

\author{
Carlos Theodoro Motta Pereira ${ }^{1}$, Fernando Cesar Carducci ${ }^{1,2}$, Lucas Mateus Rivero Rodrigues ${ }^{3}$, Luís Otávio \\ Saggion Beriam ${ }^{4}$, Luciana Harumi Shigueoka ${ }^{1}$, Valdir Mariucci Junior ${ }^{1,2}$, Kawana Silva Bortolato ${ }^{1,2}$, Gustavo \\ Hiroshi Sera ${ }^{{ }^{*}}$
}

${ }^{1}$ Instituto de Desenvolvimento Rural do Paraná - IAPAR-EMATER (IDR-Paraná), Plant Breeding Department, Rodovia Celso Garcia Cid, km 375, Zip Code 86047-902, Londrina-PR, Brazil

${ }^{2}$ Universidade Estadual de Londrina (UEL), Agronomy Department, Rodovia Celso Garcia Cid, km 380, Zip Code 86057-970, Londrina-PR, Brazil

${ }^{3}$ Instituto Agronômico (IAC) Centro de Café Alcides Carvalho, CP 28, Zip Code 13001-970, Campinas-SP, Brazil

${ }^{4}$ Instituto Biológico, CP 70, Zip Code 13012-970, Campinas-SP, Brazil

\section{*Corresponding author: gustavosera@idr.pr.gov.br}

Abstract

Bacterial-halo-blight and bacterial-leaf-spot are important coffee diseases caused by Pseudomonas syringae pv. garcae and pv. tabaci, respectively. The most suitable method to control these diseases is the use of resistant cultivars. There are no studies on resistance to Pseudomonas syringae (PS) in coffee derived from BA-10 genotypes. Therefore, the aim of this study was to evaluate the resistance to PS in lines derived from BA-10 under field conditions with simultaneous natural infections of the pathovars garcae and tabaci. $38 \mathrm{~F}_{4}$ and two $\mathrm{F}_{5}$ lines derived from BA-10 were evaluated in a field trial in Londrina, PR, Brazil. The Catuaí Vermelho IAC 81 and IAPAR 59 were the susceptible and intermediate resistant controls, respectively. Resistance to PS was evaluated in January 2017 after 45 months of planting. The grading scale varied from 1 to 5 , where grade 1 was plants with more resistance and 5 plants more susceptible. Two $F_{5}$ lines showed $100 \%$ of resistant plants (grades 1 and 2 ) and the $F_{4}$ line IAPAR 12201 showed $60 \%$ of plants with a high level of resistance to PS (grade 1), while the control Catuai showed no resistant plant. IAPAR 59 and several $F_{4}$ lines showed high frequency of plants with intermediate resistance to PS.

Keywords: bacteria, bacterial-halo-blight, bacterial-leaf-spot, Coffea arabica, Coffea liberica, IAC 1110-8.

Abbreviations: BHB_Bacterial-halo-blight; BLS_bacterial-leaf-spot; TH_Timor Hybrid; IAPAR_Instituto Agronômico do Paraná; PS_ Pseudomonas syringae; IAC_Instituto Agronômico.

Introduction

Bacterial-halo-blight (BHB) is an important coffee disease caused by the Pseudomonas syringae pv. garcae (Amaral et al., 1956), which occurs more frequently in crops of high altitude regions, with mild temperatures, high rainfall, which are exposed to strong and or constant winds, and occasional frost (Zoccoli et al., 2011). In these more favorable environmental conditions, the BHB causes losses in production in important coffee producing states of Brazil such as Minas Gerais, São Paulo and Paraná (Moraes et al., 1975; Petek et al., 2006; Ito et al., 2008; Zoccoli et al., 2011; Rodrigues et al., 2017). Besides Brazil, this disease has already been found in Kenya (Ramos and Shavdia, 1976; Ithiru et al., 2013), Ethiopia (Korobko and Wondimagegne, 1997), Uganda (Ramos and Shavdia, 1976) and China (Xuehui et al., 2013).

The BHB symptoms occur in leaves, young fruits and branches. The lesions on the leaves are irregular and of a brownish-brown color with yellowish halo around them. The lesions are more common on the edges of the leaves, where it is easier for bacteria to penetrate due to mechanical damages. However, they can extend throughout the leaf surface. In more severe attacks necrosis of branches and young fruits may occur. Young plants are more susceptible and may suffer leaf shedding, die-back of the branches, over sprouting and delayed early development (Amaral et al., 1956). Recently, P. syringae pv. tabaci was reported as a pathogenic agent of the bacterial-leaf-spot (BLS), causing symptoms in coffee leaves very similar to that of the BHB (Destéfano et al., 2010; Rodrigues et al., 2017). In the state of Paraná, the simultaneous occurrence of pathovars garcae and tabaci (Rodrigues et al., 2017) was identified.

The occurrence of these two bacterial diseases, especially the BHB, has caused significant losses in the coffee production, since the chemical control is not so efficient and there are few cultivars identified with resistance. 
The most suitable method of control is the use of resistant cultivars to $P$. syringae pv. garcae and $P$. syringae. pv. tabaci, since it is efficient and avoids the use of chemical control in coffee. Few Arabica coffee cultivars were reported with a high level of resistance to BHB. Under field conditions with natural occurrence of BHB and BLS, the susceptible cultivars were Catuaí V. IAC 81, Catucaiam 24137, Catucaí Amarelo 2SL, Japy, IPR 99, Arara, IPR 107, Acauã, Sabiá e Mundo Novo IAC 376-4. The last has been classified as highly susceptible (Fernandes et al., 2020). IPR 98, IPR 100, Tupi IAC 1669-33 (Ito et al., 2008; Andreazi et al., 2015), Bourbon, Topázio MG 1190 e IAC Ouro Verde also are susceptible to BHB (Matiello et al., 2016). Results obtained in field trials with natural occurrence of BHB and BLS showed that $C$. arabica CV. IPR 102 had a high level of resistance (Ito et al., 2008; Sera et al., 2017; Fernandes et al., 2020). Intermediate resistance was found in IAPAR 59, IPR 103, IPR 104, IPR 106, IPR 108, Catiguá MG1, Catiguá MG2, Catucaiam 2015479, IBC Palma 2 and Japiam (Ito et al., 2008; Fernandes et al., 2020). In a study with coffee seedlings inoculated with BHB and BLS, IPR 102 was reported having simultaneous resistance to both diseases, with $100 \%$ of plants resistant to BHB, but presented $33.3 \%$ of segregating plants susceptible to BLS (Rodrigues et al., 2019). In the same study, the varieties Palido Viridis and Dilla and Alghe were also reported resistant to $\mathrm{BHB}$ and $\mathrm{BLS}$. However, the latter showed susceptible plants segregating to both diseases.

Sources of resistance to BHB were identified in Arabica coffees from Ethiopia and in other species such as $C$. canephora, $C$. congensis, $C$. salvatrix, $C$. eugenioides and $C$. stenophylla (Moraes et al., 1975; Mohan et al., 1978; Rodrigues et al., 2019). Resistance to BHB was also observed in Arabica coffees with introgression of $C$. canephora genes such as in Icatu and Timor Hybrid (TH) derivatives (Mohan et al., 1978; Petek et al., 2006; Ito et al., 2008).

The genotype S288-23 was originated from the cross between the species $C$. arabica and $C$. liberica. It was classified as moderately resistant to BHB (Moraes et al., 1975), whereas this resistance probably was originated from C. liberica.

Coffee trees derived from BA series are tetraploids and they were also derived from the cross between $C$. arabica and $C$. liberica var. liberica and they were developed at the Balehonnur Experimental Station in India (Bettencourt, 1981). The Instituto Agronômico (IAC) received 10 selections from the BA series (Bettencourt, 1981), which were used in its breeding program by hybridizations with $C$. arabica cultivars such as Mundo Novo, Acaiá and Catuaí (Fazuoli et al., 2005). From these hybrids, coffee lines with SH3 rust resistance gene, drought-tolerant and high yield were produced. The first two traits were originated from the BA series (Fazuoli et al., 2005). $F_{3}$ lines derived from these BA coffees were produced by IAC to IAPAR in 1977, one of which originated from the cross between Catuaí and (Catuaí $x$ BA-10), was advanced by IAPAR to the $F_{5}$ generation and called PRFB E9705-9. The latter had simultaneous resistance to leaf rust and BHB and it was crossed with the cultivar IPR 100 , which also derived from BA-10, but susceptible to these two diseases and resistant to nematodes. $F_{4}$ lines derived from this crossing were obtained by selection of coffee plants that showed high yield, in addition to resistance to rust and nematodes.

There are no studies about resistance to Pseudomonas syringae (PS) in coffee genotypes derived from BA-10. Therefore, the aim of this study was to evaluate the resistance to PS in lines derived from BA-10, under field conditions with simultaneous natural infections of the pathovars garcae and tabaci.

\section{Results and discussion}

\section{Resistance of lines}

The mean grades of PS severity of Catuaí, IPR 100 and IAPAR 59 were $4.93,4.70$ and 3.30 , respectively, confirming the high susceptibility of the first two and the intermediate resistance of the last. Catuaí and IPR 100 had 100\% susceptible plants with grades 4 and 5 , showing that in the experiment the PS severity was very high. It was possible to classify the lines into four groups by the Scott-Knott test: group $d=20 \mathrm{~F}_{4}$ lines did not differ from Catuaí and IPR 100; group $c=17 \quad F_{4}$ lines differed from Catuaí and did not differ from the IAPAR 59; group $b=F_{4}$ line IAPAR 12201 was more resistant than IAPAR 59; group $a=F_{5}$ lines, PRFB E9705-9 and IAPAR 11390, were the most resistant (Table 1).

The most resistant $F_{4}$ line IAPAR 12201 presented a mean grade of 2.20 and $60 \%$ of resistant plants with grade 1 , but $40 \%$ of the plants were susceptible (Table 1). The intermediate resistance check, IAPAR 59, presented $43.75 \%$ of plants with grades 4 and 5 . As we detected a mixture of the garcae and tabaci pathovars in the experiment, it is not possible to state whether IAPAR 12201 and IAPAR 59 are homozygous or heterozygous for resistance. One of the hypotheses is that $40 \%$ of plants with grades 3 and 5 observed in the line IAPAR 12201 and $43.75 \%$ of plants with grades 4 and 5 of IAPAR 59 may have occurred because these two genotypes have simultaneous resistance to both bacteria and are in heterozygous condition. The second hypothesis is that they have resistance in homozygosis only to one of the bacteria (e.g. patovar garcae) and are susceptible to the other (e.g. patovar tabaci). The third hypothesis is that the intermediate resistance observed in IAPAR 59 can be quantitative type, governed by many genes. This type of resistance is highly influenced by the environment, so it is possible that plants with intermediate resistance could have an increase in the intensity of the disease, when exposed to an environment very favorable to the pathogen. This could be the explanation for the observation of $12.50 \%$ of plants with grades 5 in IAPAR 59. But this percentage was much lower than those observed in the cultivars Catuai and IPR 100with 70 and 93.75\%, respectively.

Currently, only the cultivar IPR 102 was identified with a high level of resistance to BHB (Ito et al., 2008; Sera et al., 2017; Rodrigues et al., 2019; Fernandes et al., 2020) and BLS (Rodrigues et al., 2019). IAPAR 12201 is the $F_{4}$ line that has the highest potential to become a cultivar with a high level of resistance to Pseudomonas syringae; and therefore, will be advanced to the next generation of self-pollination. PRFB E9705-9 and IAPAR 11390 presented 100\% resistant plants, which probably have homozygous resistance for both PS patovars. PRFB E9705-9 and IAPAR 11390 are in the F5 generation and also have the potential to become new cultivars with resistance to PS or can be used as sources of resistance in breeding programs.

Both Catuaí and IPR 100 did not have any susceptible plants with grade 3, predominating those of grade 5, while the F4 lines presented a frequency of plants with grade 3 ranging from 6.25 to $87.50 \%$, indicating that these have an intermediate resistance, which can be quantitative. In the same way as was previously cited for IAPAR 59, these lines 
Table 1. Means of Pseudomonas syringae (PS) severity and plant frequency according to the grade scale from 1 to 5 of $P S$, in $38 F_{4}$ lines derived from the crossing "PRFB E9705-9" x IPR 100 and two $F_{5}$ lines derived from 'Catuai V. IAC 81' x (Catuaí V. IAC $81 \times$ IAC 1110-8), evaluated under field conditions with simultaneous natural infections of the pathovars garcae and tabaci, in Londrina (PR, Brazil).

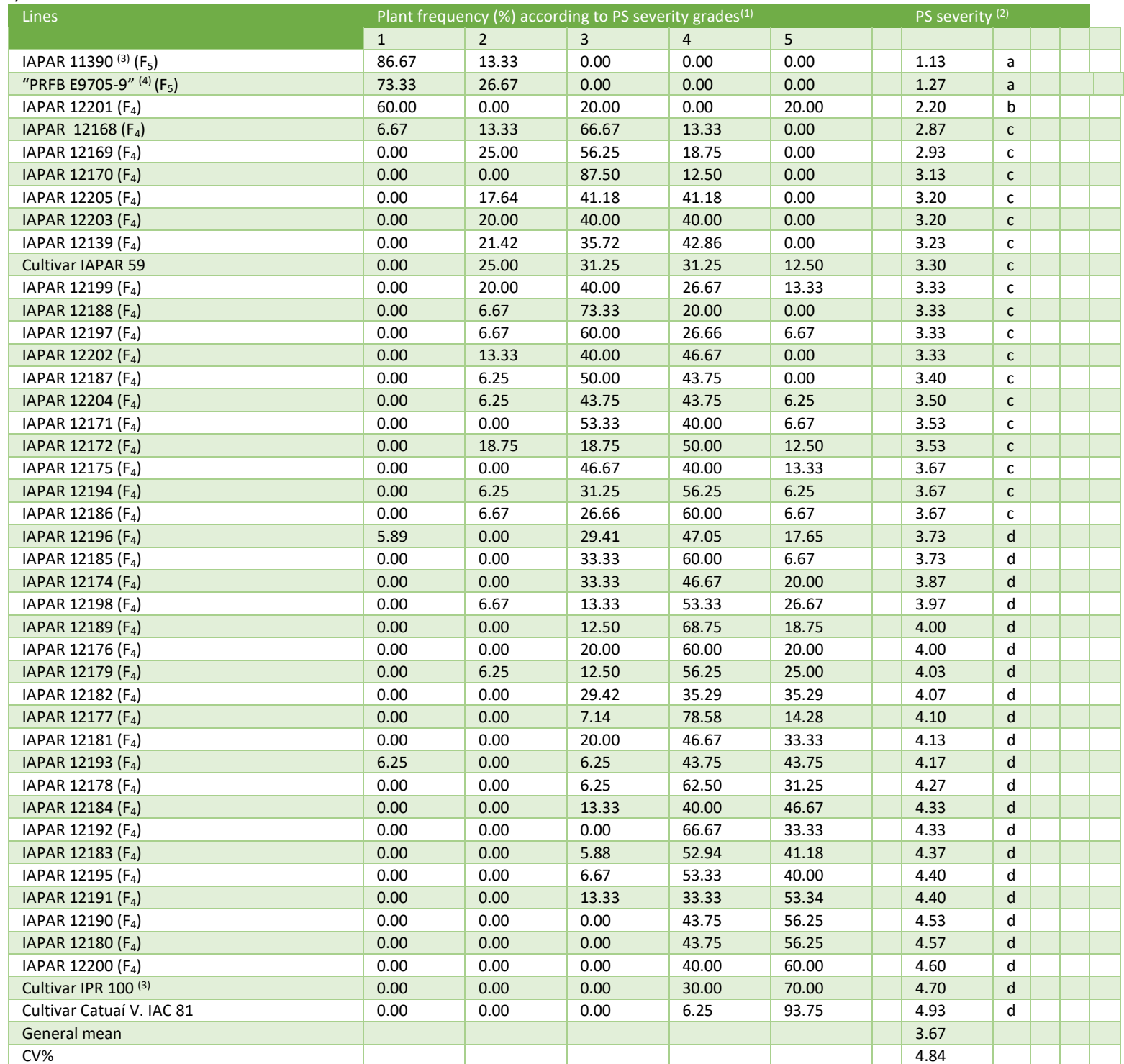

(1) Scale of grades from 1 to 5 of the $P$. syringae severity, where 1 is the most resistant and 5 the most susceptible. (2) Means followed by the same letter do not differ by the Scott-Knott mean clustering test $(\alpha=5 \%$ ). Data transformed by $\sqrt{x+1}$. (3) Originated from H8721 (plant 1420 of 'Catuaí V. IAC 81 ' $\mathrm{x}$ "H7314-4"). (4) Originated from H8598 (plant 1412 of 'Catuaí V. IAC 81' x “H7314-5”).

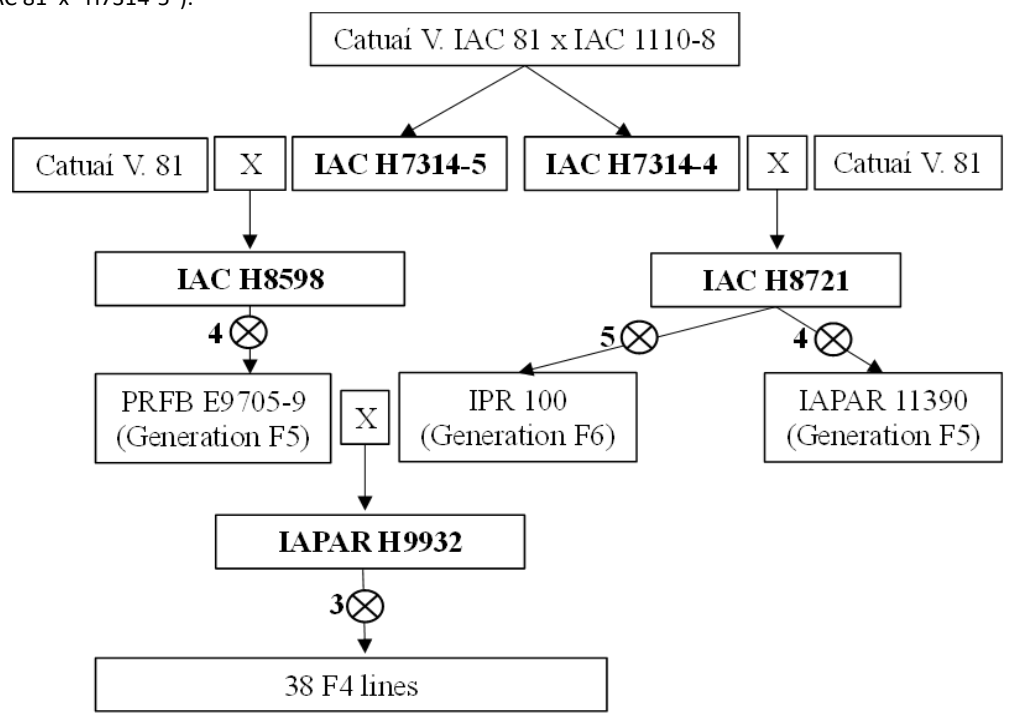

Fig 1. Pedigree of F4 lines derived from IAPAR H9932 and F5 lines named PRFB E9705-9 and IAPAR 11390. = self-pollination; X= hybridization 
may have an intermediate resistance in heterozygous for the two bacteria or homozygous for one of them. Under a natural occurrence of BHB and BLS, IPR 106 and Japiam, derived from Icatu, Catiguá MG 2, Catiguá MG 1 and IBC Palma 2, which derived from $\mathrm{TH}$, showed moderate resistance (Fernandes et al., 2020). Other studies also reported the possibility of the existence of quantitative resistance to $\mathrm{BHB}$ in genotypes derived from $\mathrm{TH}$ and Icatu (Petek et al., 2006; Ito et al., 2008).

\section{Source of resistance}

$\mathrm{F}_{4}$ lines were derived from the crossing "PRFB E9705-9" x IPR 100 and the likely source of resistance was "PRFB E9705-9", as the latter showed $100 \%$ of resistant plants, while IPR 100 and Catuaí V. IAC 81 were susceptible (Table 1). "PRFB E9705-9" was originated from the hybrid H8598 (plant 1412 of 'Catuaí V. IAC $81^{\prime}$ x “H7314-5”) and H7314 is a hybrid between 'Catuaí V. IAC 81' and IAC 1110-8. IAPAR 11390 and IPR 100 were originated from H8721 (plant 1420 of 'Catuaí V. IAC 81' x "H7314-4") (Fig 1). However, the first presented $100 \%$ of resistant plants and the second $100 \%$ of susceptible plants (Table 1). Although these two were originated from the same $F_{1}$ plant of $H 8721$, only the $F_{5}$ line IAPAR 11390 was resistant, because in previous segregant generations resistant plants were selected, whereas for IPR 100 this was not done. As "PRFB E9705-9" and IAPAR 11390 were resistant, PS resistance was originated from H7314-4 and H7314-5, which had the resistance originated from IAC 11108. The latter, also called BA-10, is a Coffea arabica with introgression of $C$. liberica genes, which may have been the source of original resistance. Rodrigues et al. (2019) studied the seedlings of $C$. liberica var. liberica, and artificially inoculated them with BHB. They observed $6.3 \%$ of resistant plants, $31.2 \%$ moderately resistant and $62.5 \%$ of susceptible. The main source of resistance to BHB used by breeding programs is wild Ethiopian Arabica coffees (Sera, 2001). Our study is the first to report resistance to PS in coffee genotypes derived from BA-10. In another study, the genotype S288-23, also carrier of $C$. liberica genes, presented moderate resistance to BHB (Moraes et al., 1975).

\section{Materials and methods}

\section{Plant materials}

A total of $38 \mathrm{~F}_{4}$ lines derived from the hybrid IAPAR H9932 ("PRFB E9705-9" x IPR 100) were evaluated. The cultivars Catuaí Vermelho IAC 81 and IPR 100 were the susceptible checks and IAPAR 59 was the intermediate resistant check (Ito et al., 2008). The $F_{5}$ lines "PRFB E9705-9" and IAPAR 11390 also were evaluated. "PRFB E9705-9" was originated from the hybrid IAC H8598 (plant 1412 of 'Catuaí V. IAC 81' $\mathrm{x}$ "IAC H7314-5"). IAPAR 11390 and IPR 100 were originated from IAC H8721 (plant 1420 of 'Catuaí V. IAC 81' x "IAC H7314-4"). IAC H7314-4 and IAC H7314-5 are hybrids between 'Catuaí V. IAC 81' and IAC 1110-8 (Fig 1). Also known as BA-10, the genotype IAC $1110-8$ was originated from the coffee plants of the BA series from India, and it is a C. arabica with introgression of $C$. liberica var. liberica.

\section{Field trial}

The field trial was installed in April 2013 at the IAPAR experimental station (lat 2321'44" S, long 5109'49" W, alt $582 \mathrm{~m}$ asl), in Londrina, Paraná state, Brazil. The climate is classified as Cfa, according to Köppen. The average annual temperature in Londrina is $21.1^{\circ} \mathrm{C}$ and the annual average precipitation varies from 1400 to $1600 \mathrm{~mm}$ per year. The experiment was planting at $2.50 \mathrm{~m}$ spacing inter-row and $0.70 \mathrm{~m}$ within row, using randomized blocks design, with three replications and five plants per plot.

Soil fertilization and corrections, besides agricultural practices, were made according to the recommendation for coffee crop (Matiello et al., 2016). In the years 2016 and 2017, antibiotics, resistance inducers and copper-based products were not applied, which could reduce the PS intensity.

\section{Identification of the pathovars of Pseudomonas syringae}

A sample composed of 60 leaves of this experiment was sent to the Biological Institute, Campinas-SP, Brazil to identify pathogens.

The obtained isolates were submitted to the LOPAT tests (levan, oxidase, protopectinase in potato disks, arginine dihydrolase, and tobacco $\mathrm{HR}$ ) and fluorescent pigment in BK medium (King et al., 1956). All strains presented the results,

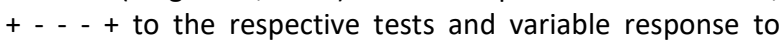
fluorescent pigment, indicating the inclusion of the obtained isolates in Group I of $P$. syringae.

Subsequently, the strains were subjected to biochemical (Lelliot et al, 1966; Young and Triggs, 1994; Schaad, 2001; Rodrigues et al, 2017) and pathogenicity tests. The results determined the occurrence of $P$. syringae pv. garcae, causal agent of the $\mathrm{BHB}$ and $P$. syringae pv. tabaci, causal agent of $\mathrm{BLS}$, in the experimental field.

\section{Resistance assessment}

An assessment of the PS severity was made in January 2017 (45 months after planting), based on the symptoms described by Amaral et al. (1956). Severity was evaluated in natural infection condition of pathovars garcae and tabaci, using a grade scale, ranging from 1 to 5 (Sera et al., 2017), in which: 1 = no necrotic lesions; $2=0.01$ to $3 \%$ of the leaves with small necrotic lesions, with yellowish halo (up to 0.5 $\mathrm{cm}) ; 3=3.01$ to $15 \%$ of the leaves with small and medium lesions (up to $1 \mathrm{~cm}$ ), with possible presence of $1 \%$ large lesions (greater than $1 \mathrm{~cm}$ ); $4=15.01$ to $30 \%$ of the leaves with small to large lesions; $5=$ more than $30 \%$ of the leaves with small to large lesions, with possible die-back of the branches. Disease severity was evaluated in the whole plant, from the upper third to the lower third of the plant canopy. However, only unexpanded young leaves to tenth pair of fully expanded leaves were considered. This was done because the leaves located further inside the plant had low disease severity or no lesions.

Plants with grades 1 and 2 were considered resistant and with grades 3,4 and 5 as susceptible.

\section{Statistical analysis}

PS severity data were transformed to $\sqrt{x+1}$ at level of mean of plots. ANOVA, Bartlett test of homogeneity of variances, Shapiro-Wilk normality test and Scott-Knott mean clustering test at $5 \%$ significance were performed using the $\mathrm{R}$ software version 3.3.0 ( $\mathrm{R}$ Core Team, 2016), package ScottKnott (Jelihovschi et al., 2014).

\section{Conclusion}

Two $\mathrm{F}_{5}$ lines, derived from $\mathrm{BA}-10$, showed $100 \%$ of resistant plants to PS. The $F_{4}$ line IAPAR 12201, also derived from BA10 , showed a high frequency of PS resistant plants. Several $\mathrm{F}_{4}$ lines showed high frequency of plants with intermediate 
resistance to PS. The cultivar IPR 100 was susceptible and IAPAR 59 showed intermediate resistance.

\section{Acknowledgments}

We thank Consórcio Pesquisa Café for the financial support to this research.

\section{References}

Amaral JF, Teixeira GC, Pinheiro ED (1956) A bactéria causadora da "Mancha Aureolada" do cafeeiro. Arqu do Instituto Biológico. 23:151-155.

Andreazi E, Sera GH, Faria RT, Sera T, Shigueoka LH, Carvalho FG, Carducci FC, Chamlet D (2015) Desempenho de híbridos $\mathrm{F} 1$ de café arábica com resistência simultânea a ferrugem, mancha aureolada e bicho mineiro. Coffee Sci. 10:375-382.

Bettencourt AJ (1981) Melhoramento genético do cafeeiro: transferência de fatores de resistência à Hemileia vastatrix Berk. \& Br. para as principais cultivares de Coffea arabica L. Lisboa: Junta de investigações cientificas do ULTRAMARC/Centro de Investigação das Ferrugens do Cafeeiro, Oeiras, $93 \mathrm{p}$.

Destéfano SAL, Rodrigues LMR, Beriam LOS, Patrício FRA, Thomaziello RA, Rodrigues Neto J (2010) Bacterial leaf spot caused by Pseudomonas syringae pv. tabaci in Brazil. New Dis Rep. 22:5.

Fazuoli, LC, Oliveira ACB de, Toma-Braghini M, Silvarolla MB (2005) Identification and use of sources of durable resistance to coffee leaf rust at the IAC. In: Zambolim L, Zambolim EM, Várzea VMP (eds). Durable resistance to cofee leaf rust. UFV, Viçosa, p.137-185.

Fernandes LE, Santos WG dos, Carducci FC, Fonseca IC de B, Rodrigues LMR, Beriam LOS, Pereira CTM, Shigueoka LH, Sera GH (2020) Resistance of Arabica coffee cultivars to leaf wounds and Pseudomonas syringae under field conditions. Austr J Crop Sci. 14:46-50.

Ithiru JM, Gichuru EK, Gitonga PN, Cheserek JJ, Gichimu BM (2013) Methods for early evaluation for resistance to bacterial blight of coffee. African J Agric Res. 8:2450-2454.

Ito DS, Sera T, Sera GH, Del Grossi L, Kanayama FS (2008) Resistance to bacterial blight in arabica coffee cultivars. Crop Breeding and Appl Biotechnol. 8:99-103.

Jelihovschi EG, Faria JC, Allaman IB (2014) ScottKnott: A Package for Performing the Scott-Knott Clustering Algorithm in R. Trends in Appl and Computational Math. 15:3-17.

King EO, Ward MK, Raney DE (1956) Two simple media for the demonstration of pycoyanin and fluorescein. J Lab Clin Med. 4:301-307.

Korobko A, Wondimagegne E (1997) Bacterial blight of coffee (Pseudomonas syringae pv. garcae) in Ethiopia. In:
Rudoldh K, Burr TJ, Mansfield JW, Stead D, Vivian A, Von Kietzele J. Pseudomonas syringae and related patogens. Netherlands Springer. $p$ 538-541.

Lelliott RA, Billing E, Hayward AC (1966) A determinative scheme for the fluorescent plant pathogenic pseudomonads. J of Appl Microbiol. 29:470-489.

Matiello JB, Santinato R, Almeida SR, Garcia AWR (2016) Cultura de café no Brasil: Manual de recomendações. ed. 2015. Futurama Editora, Varginha, MG.

Mohan SK, Cardoso RL, Pavan MA (1978) Resistência em germoplasma de Coffea ao crestamento bacteriano incitado por Pseudomonas garcae Amaral et al. Pesquisa Agropecuária Brasil. 13:53-64.

Moraes SA, Sugimori MH, Tomazello-Filho M, Carvalho P de CT de (1975) Resistência de cafeeiros a Pseudomonas garcae. Summa Phytopathol. 1:105-110.

Petek MR, Sera T, Sera GH, Fonseca IC de B, Ito DS (2006) Seleção de progênies de Coffea arabica com resistência simultânea à mancha aureolada e à ferrugem alaranjada. Bragantia. 65:65-73.

R Core Team (2016) R: A language and environment for statistical computing. R Foundation for Statistical Comput Vienna.

Ramos AH, Shavdia LD (1976) A dieback of coffee in Kenya. Plant Dis Rep Washington. 60:831-835.

Rodrigues LMR, Destéfano, SAL, Almeida IMG de, Beriam LOS, Braghini, MT, Guerreiro-Filho O (2019) Multiple resistance to bacterial halo blight and bacterial leaf spot in Coffea spp. Arq do Instituto Biológico. 86:1-9.

Rodrigues LMR, Sera GH, Guerreiro Filho O, Beriam LOS, Almeida IMG de (2017) First report of mixed infection by Pseudomonas syringae pathovars garcae and tabaci on coffee plantations. Bragantia. 76:543-549.

Schaad NW, Jones JB, Chun W (2001) Laboratory guide for the identification of plant pathogenic bacteria (ed 3). Am Phytopathol Soc (APS Press). p 373.

Sera GH, Sera T, Fazuoli LC (2017) IPR 102 - Dwarf Arabica coffee cultivar with resistance to bacterial halo blight. Crop Breeding and Appl Biotechnol. 17:403-407.

Sera T (2001) Coffee Genetic Breeding at IAPAR. Crop Breeding and Appl Biotechnol. 1:179-199.

Xuehui B, Lihong Z, Yongliang H, Guanghai J, Jinhong L, Zhang H. (2013) Isolation and identification of the pathogen of coffee bacterial blight disease. Chin J Trop Crop. 34:738742.

Young, JM, Triggs CM. (1994) Evaluation of determinative tests for pathovars of Pseudomonas syringae van Hall 1902. J of Appl Microbiol. 77:195-207.

Zoccoli DM, Takatsu A, Uesugi CH (2011) Ocorrência de mancha aureolada em cafeeiros na Região do Triângulo Mineiro e Alto Paranaíba. Bragantia. 70:843-849. 